\title{
PARA OS SÚDITOS DE MOMO, TRADIÇÃO É LEI: GOVERNO EVERDADE NA ORGANIZAÇÃO DO CARNAVAL DE OLINDA
}

\author{
For the subjects of Momo, tradition is law: government and truth in \\ the organization of Olinda's Carnival
}

\author{
Suélen Matozo Franco* \\ André Luiz Maranhão de Souza Leão**
}

\section{RESUMO}

O Carnaval de Olinda é um dos mais importantes eventos da vida cultural da cidade e está entre os maiores carnavais do Brasil. Como em diversos carnavais do Brasil, sua configuração resulta de um projeto identitário implantado nos anos finais da década de 1970 , rompendo com o modelo recifense e resultando num "autêntico" Carnaval de rua. Desde então, esse novo modelo é defendido como uma tradição, e sua permanência e suas transformações inscrevem-se numa complexa teia de poder e resistência, envolvendo desde os participantes da folia até as instâncias decisórias do festejo. Assim, investigamos como a tradição é articulada enquanto exercício de poder no Carnaval de Olinda. Para tanto, realizamos uma análise de discurso foucaultiana da cobertura jornalística de quatro Carnavais olindenses (1986, 1996, 2006 e 2016). Nossos achados revelam essa tradição como um regime de verdade, perpassado por tensões que envolvem processos de legitimação, normatização e resistência.

Palavras-chave: Carnaval de Olinda. Tradição. Governo. Regime de Verdade. Poder.

\begin{abstract}
The Carnival of Olinda is one of the most important events in the city's cultural life and is one of the largest carnivals in Brazil. As in several carnivals in Brazil, its configuration results from an identity project implemented in the late 1970s, breaking with the model from Recife and resulting in an "authentic" street Carnival. Since then, this new model is defended as a tradition, and its permanence and transformations are inscribed in a complex web of power and resistance, involving from the participants of the revelry to the decisive instances of the celebration. Thus, we investigate how tradition is articulated as an exercise of power in the Carnival of Olinda. To do so, we performed a Foucauldian discourse analysis of the journalistic coverage of four Carnivals of Olinda (1986, 1996, 2006 and 2016). Our findings reveal this tradition as a regime of truth, permeated by tensions involving processes of legitimacy, normalization and resistance.
\end{abstract}

Keywords: Carnival of Olinda. Tradition. Govern. Regime of Truth. Power.

\footnotetext{
* Doutora em Administração pela Universidade Federal de Pernambuco (UFPE) - Recife (PE), Brasil. E-mail: suelenmfranco@gmail.com. ORCID: 0000-0001-7835-9257

** Doutor em Administração pela Universidade Federal de Pernambuco (UFPE). Professor Associado do Programa de Pós-graduação em Administração da Universidade Federal de Pernambuco (Propad/UFPE) - Recife (PE), Brasil. E-mail: aleao21@hotmail.com. ORCID: 0000-0002-7660-5845
} 


\section{INTRODUÇÃO}

O município de Olinda, em Pernambuco, é considerado Patrimônio Cultural da Humanidade, título concedido pela Unesco em 1982, e primeira Capital Brasileira da Cultura, honraria concedida no ano de 2005 pela organização não governamental Capital Brasileira da Cultura (OLINDA, 2016). Entre os pontos mais notáveis da sua cultura está o Carnaval, um dos mais famosos do Brasil (HARCHAMBOIS; PONTUAL, 2007). Embora guarde inúmeras semelhanças com o Carnaval da vizinha e capital Recife, em Olinda considera-se a principal característica do festejo a participação dos próprios brincantes, tanto na fruição quanto na organização (ATAÍDE, 1982; HARCHAMBOIS; PONTUAL, 2007; LEAL, 2008). Tamanha é sua importância para o município que o festejo é regido pela Lei $n^{\circ}$ 5.306/01, a Lei do Carnaval, bem como pelo Plano Municipal de Cultura. Ambos os instrumentos, apesar de elaborados no âmbito da Administração Pública, enfatizam a participação popular como uma importante premissa.

relação entre o Carnaval e as estruturas sociais no Brasil pode ser vista sob lentes distintas. Para DaMatta (1997), o Carnaval encarna uma ruptura com os padrões operativos de uma sociedade e com a ordem vigente. Já Queiroz (1992) questiona esse entendimento, apresentando evidências de como o Carnaval endossa a lógica vigente, tais como: o enaltecimento do trabalho e o disciplinamento dos estratos populares operado pelas escolas de samba; a utilização das mulheres como mercadoria e atração nos grandes bailes; e a divisão espacial dos salões, denunciando, com isso, um sofisticado mecanismo de se obter das massas o consentimento em relação às opressões que elas acreditam estar combatendo.

Embora os diversos municípios do Brasil guardem suas peculiaridades com relação ao Carnaval, é possível identificar uma "ordem carnavalesca" comum aos mais diversos festejos, cujos papéis sociais e hierarquias socioeconômicas vigentes são apenas reforçadas, à medida que se revestem de uma emoção carnavalesca e uma suposta fraternidade e igualdade (QUEIROZ, 1994) Talvez por essa ordem, o Carnaval tenha sido facilmente apropriado pelo projeto de construção de uma identidade nacional (QUEIROZ, 1994; VIDAL; ANDRADE, 2009) Em Pernambuco, a consolidação da República, o advento do Estado Novo e o golpe de 1964 moldaram o Carnaval enquanto manifestação cultural de utilidade pública: este último acontecimento consagrou no Recife o Carnaval espetáculo, marcado pelas arquibancadas (VIDAL; ANDRADE, 2009), em detrimento do Carnaval participação, marcado pelo uso intensivo do espaço público.

No intuito de demarcar uma oposição a esse modelo, em Olinda, no fim da década de 1970, a gestão municipal aboliu as passarelas e comissões julgadoras, consagrando a rua como espaço de folia e a participação como premissa (HARCHAMBOIS; PONTUAL, 2007), premissa esta institucionalizada em instrumentos da gestão pública municipal. Marca-se, então, o início de um modelo de festejo evocado até os dias atuais como uma tradição - esta, por sua vez, perpassada por uma dinâmica de preservação, questionamentos e resistência. Mas seria coerente chamar de tradição um projeto identitário deliberadamente estabelecido em um passado recente?

Nos termos de Hobsbawm (1984), poderíamos falar em "tradição inventada". No entanto, para além de uma essência, continuidade ou vínculo "autêntico" com os ante- 
passados, buscamos entender as condições de possibilidade e emergência dessa tradição com ênfase nas práticas de organização e fruição desse festejo. Assim, refletimos à luz do pensamento foucaultiano, que se opõe à noção de essência e origem, buscando as descontinuidades, dispersões e condições de produção (OLIVEIRA, 2008). Essas condições de produção, por sua vez, apontam para as questões de poder e como estas se relacionam com as práticas discursivas.

A analítica do poder empreendida por Michel Foucault, a partir dos anos 1970, rompe com a concepção estável para investigar esse fenômeno enquanto relação de forças que emergem num determinado momento histórico (DREYFUS; RABINOW, 2011). Essa analítica recusa a ideia de origem e atém-se à emergência, lançando um olhar à dimensão processual, e não aos pontos de surgimento dessas relações (THIRY-CHERQUES, 2010). Assim, em vez de circunscrever o poder às instituições, propõe-se, pelo contrário, a analisar as instituições a partir das relações de poder (MAGALHÃES, 1997).

Dessa forma, considerando o Carnaval um campo fecundo de investigação dessas relações de poder, resistência e tensões entre grupos sociais (SOIHET, 1999), buscamos resgatar as relações de poder na organização do Carnaval de Olinda, considerando que a configuração vigente é relativamente nova (pós-1970) e articula-se em um ideal de tradição e autenticidade, conforme veremos adiante. 0 presente estudo, de inspiração foucaultiana, não busca apreender a organização circunscrita às instituições formais envolvidas no fazer carnavalesco, mas as relações que perpassam os mais diversos agentes e resultam na configuração atual do festejo. Assim, compreendendo a ideia de tradição como um importante esteio da identidade do festejo assumida após os anos 1970, lançamos o questionamento: como a tradição é articulada enquanto exercício de poder no Carnaval de Olinda?

O presente estudo justifica-se pelo intuito de lançar uma contribuição ao crescente interesse que o campo dos estudos organizacionais tem demonstrado pelos Carnavais do Brasil (HOLLANDA, 2013), abordando um dos maiores do País, cuja visibilidade midiática é elevada, mas é ainda incipiente no âmbito acadêmico. O pensamento de Michel Foucault é amplamente utilizado nos estudos organizacionais, sendo sua contribuição muitas vezes reduzida à questão da disciplina, embora permita aprofundar discussões sobre a dinâmica poder-resistência (MOTTA; ALCADIPANI, 2004). Suas análises permitem transpor os limites das organizações formais, propiciando uma análise organizacional que enfoque princípios e processos de organizar onde quer que eles ocorram, pois qualquer que seja a atividade organizacional envolverá saber, poder e subjetividade (KNIGHTS, 2004)

\section{CARNAVAL NO BRASIL: DE PROJETO IDENTITÁRIO A TRADIÇÃO}

O Carnaval é reconhecidamente uma das festas públicas mais antigas no mundo. Sua chegada ao Brasil deu-se com a colonização, sendo sua primeira manifestação o entrudo, em que se arremessavam farinha, água, ovos uns contra os outros (SEBE, 1966; ARAúJO, 1996). O historiador Luís da Câmara Cascudo chegou a afirmar que não tivemos Carnaval, numa alusão à curta permanência do entrudo e à dominação da festa pelos interesses da elite, minando a essência do que acreditava ser o verdadeiro Carnaval, uma festa do povo, tendo, portanto, no entrudo sua manifestação mais autêntica (NÓBREGA, 2012). 
Um aspecto inerente aos festejos carnavalescos é a dicotomia público-privado, que permeia sua história desde as raízes europeias. Essa dicotomia é um dos aspectos que evidencia a tensão entre o carnaval popular e o intuito de instauração de um modelo burguês, não se limitando a uma demarcação de espaço meramente de ordem física, mas também social, simbólica, sendo o espaço privado, o interior de clubes e agremiações, uma espécie de filtro que selecionava os brincantes, embora a rua fosse, por excelência, o espaço destinado ao festejo (ARAÚJO, 1996). No contexto carioca, Queiroz (1992) traça a distinção entre Grande Carnaval e Pequeno Carnaval, sendo o primeiro festejado pelas elites, com ricas fantasias, carros e salões ornamentados, e este último, por operários negros e pardos ao som de músicas afro, constituindo-se no embrião das primeiras escolas de samba.

Na transição do século XIX para o XX, sobretudo com o advento do modernismo, a busca por uma identidade nacional e pela consagração de uma cultura autêntica resultou na tentativa de revestir o Carnaval brasileiro de uma "tradição", sendo este um conceito que aglutinaria elementos de origens diversas, nem sempre compatíveis, ou mesmo suficientemente antigos (QUEIROZ, 1992). O reconhecimento do festejo como importante recurso para a tão desejada construção de identidade nacional opera uma importante reconfiguração na gestão do festejo e em sua relação com o Estado (VIDAL; ANDRADE, 2009). Em Pernambuco, o processo de institucionalização do festejo tem como marco a criação da Federação Carnavalesca Pernambucana (VIDAL; ANDRADE, 2009; ARAÚJO, 1996; HARCHAMBOIS; PONTUAL, 2007). A entidade encarregou-se de moldar o Carnaval ao projeto político do Estado getulista, alinhando-se aos grupos políticos no poder e obtendo paulatinamente sua simpatia, chegando a ser cooptada pelo Estado Novo, durante a gestão de Carlos de Lima Cavalcanti, quando o Carnaval se tornava uma manifestação cultural de utilidade pública (VIDAL; ANDRADE, 2009).

A disciplina e a governabilidade são, sob a perspectiva dos estudos culturais e foucaultianos, maneiras de internalizar o controle social, sendo a cultura um importante veículo nesse processo (YúDICE, 2013). No caso do Carnaval, isso torna-se evidente à medida que a desaprovação de diversas agremiações por elites e autoridades começa a dar espaço à normatização, ou mesmo a subvenção, quando as autoridades passam a reconhecer seu valor na criação de uma identidade, bem como do seu potencial de disciplinamento. Trata-se de um mecanismo pelo qual o Estado se apropria das práticas populares, reinterpreta-as e apresenta o resultado desse processo como uma manifestação genuína da identidade nacional, sendo o Carnaval um exemplo emblemático desse processo (ORTIZ, 1994). Yúdice (2013) atribui esse processo à absorção do festejo por uma racionalidade econômica, inserindo-o no quadro epistêmico da sociedade disciplinar, de Michel Foucault. A cooptação do festejo pelos projetos políticos, no entanto, era perpassada por debates e resistências, na medida em que muitas vezes silenciava práticas populares em prol daquilo que se pretendia dizível sobre a projeto identitário que então se construía (VIDAL, 2010). O Carnaval pernambucano vai-se moldando aos interesses dos diversos grupos dominantes, tanto no plano político quanto no econômico, a exemplo do modelo de carnaval espetáculo, em detrimento da participação, consagrado em Pernambuco em decorrência das novas diretrizes de política cultural pós-golpe de 1964 (VIDAL; ANDRADE, 2009).

No município de Olinda, que dista menos de $7 \mathrm{~km}$ do Recife, o Carnaval de rua tem suas primeiras expressões culturais no início do século $X X$, com o surgimento das agremiações carnavalescas (HARCHAMBOIS; PONTUAL, 2007). Embora guarde inúmeras 
semelhanças com o festejo da vizinha Recife, o Carnaval de Olinda é reconhecido pela participação dos próprios brincantes, tanto na fruição quanto na organização (ATAÍDE, 1982; HARCHAMBOIS; PONTUAL, 2007; LEAL, 2008).

As primeiras agremiações de Olinda nascem pela iniciativa de famílias moradoras ou veranistas do Sítio Histórico, que passam a tradição de organizar os desfiles às gerações subsequentes, resultando numa preocupação com uma "preservação de autenticidade" .(ATAÍDE, 1982). Mas, segundo o autor, a participação dos brincantes não exclui a institucionalização do festejo e a presença da gestão pública nas instâncias decisórias, tendo havido, na década de 1950, um processo de profissionalização e municipalização do evento. Já nos anos finais, a abolição de comissões julgadoras, passarelas e palanques no Sítio Histórico, bem como um engajamento mais efetivo dos próprios moradores na organização do festejo (HARCHAMBOIS; PONTUAL, 2007), assinala a ruptura com o modelo de Carnaval espetáculo vigente na capital Recife e consagra o modelo de participação em Olinda. No ano de 2001, com a Lei no 5.306/01 (Lei do Carnaval), esse modelo participativo é formalizado como característica do festejo em Olinda, o que é corroborado pelo Plano Municipal de Cultura, que também orienta a realização do festejo.

É sabido que a tensão entre espaço público e privado não é exclusiva do Carnaval brasileiro, tampouco do olindense. No entanto, a participação como traço identitário do Carnaval olindense, constantemente evocada, leva-nos a supor um espaço público plenamente ocupado por foliões sem que sobre eles incidam distinções de quaisquer ordens, uma premissa que Queiroz (1994) contraria ao estudar carnavais de cidades menores que fogem ao modelo de arquibancada, enfatizando que a separação entre espectador e ator/folião, ainda que menos contundente, manifesta-se com clareza no uso do espaço público.

Essa clara oposição do Carnaval de Olinda ao modelo de passarelas e comissões é um dos principais esteios daquilo que defendem como tradição e autenticidade no Carnaval de Olinda. Para Queiroz (1992), no entanto, o Carnaval de Olinda é um exemplo de como se configurou uma narrativa de um festejo desprovido de formalismos, fato que a autora credita a um projeto de intelectuais e artistas radicados no Sítio Histórico na década de 1970, endossado por habitantes mais velhos da cidade e profundamente ancorado na estratificação social existente.

Nesse sentido, a ruptura operada na década de 1970 aproxima-se do que Hobsbawm (1984) define como tradição inventada: um projeto deliberado, com um sistema explícito ou tácito de normas, no qual a tradição é evocada na remissão a um passado longínquo e há busca de um sentido de continuidade em relação aos antepassados. Burke (2005), no entanto, questiona a tradicional concepção de tradição, na medida em haveria tensão entre persistência e inovação, aspectos universais e situações específicas das tradições. Essa suposta incompatibilidade entre tradição e transformação, por sua vez, revela uma ênfase estrita nos elementos de uma tradição que a desvincula das condições materiais e do contexto de criação (CATENACCI, 2001).

O presente estudo, de orientação pós-estruturalista, parte da reflexão teórica foucaultiana para pensar a noção de tradição no contexto do Carnaval de Olinda. De inspiração nietzschiana, essa reflexão recusa a busca por uma origem, pois isso implicaria assumir a existência de uma essência exata, quando, na verdade, cabe-nos questionar tal essência (FOUCAULT, 2015). Em sua Arqueologia de saber, Foucault (2014a) ressalta a impor- 
tância para uma análise histórica de despir-se de quaisquer noções que pressuponham continuidade, dentre as quais destaca a de tradição, como algo que confere singularidade e agrupamento a fenômenos contíguos, aglutinando diferenças, conferindo-Ihes uma noção de origem e isolando "novidades" sob uma ideia de permanência em torno das quais estas despontam. Ele advoga, portanto, a necessidade de questionar esses "agrupamentos familiares", examinando as forças que unem os diversos discursos que os constituem. Dessa forma, a tradição, tal como outras definições que pressupõem continuidade, pode ser entendida como o resultado de práticas discursivas e não discursivas que se articulam.

Ao ampliar o escopo de suas investigações para as realidades não discursivas, ao mesmo tempo que a problemática do poder ganha ênfase em suas análises (REVEL, 2005), emerge a noção de dispositivo, definido por Foucault (2015) como uma rede de elementos heterogêneos e de cunho estratégico, tais como discursos, instituições, organizações arquitetônicas, leis, regulamentos, aspectos morais, que respondem a uma urgência. Sua natureza estratégica pressupõe uma relação de forças em constante reconfiguração inscrita num jogo de poder, envolvendo, portanto, realidades não discursivas. Nesse sentido, podemos entender a noção de tradição ora trabalhada, sob a perspectiva foucaultiana que orienta a presente análise, como um dispositivo, tendo em vista que as noções de tradição e autenticidade relativas ao Carnaval olindense pressupõem uma série de relações de força, ditos, não-ditos, instituições e estratos sociais. Ao entender a tradição como um dispositivo, cumpre-nos investigá-la tal como propõe a analítica foucaultiana: buscando, nos mecanismos de produção de saberes e multiplicação de discursos, suas condições de surgimento e as estratégias de poder imanentes a esses saberes (FOUCAULT, 2014c).

Dessa forma, para Foucault, mais importante que a noção de continuidade inerente às concepções clássicas de tradição, são as rupturas, os acidentes (em vez de "evolução"), interessando-Ihe os sistemas de classificação e os regimes de verdade que se materializam como expressões de uma cultura e forças que a moldam (BURKE, 2005). Sua obra posiciona-se contra essencialismos, no combate às noções de origem e continuidade, tão caras à história tradicional, e na renúncia a uma verdade transcendente (OLIVEIRA, 2008). Assim, não assumimos a tradição como uma invenção a priori, tendo em vista que a presente investigação lança um olhar aos regimes de visibilidade e resistência que delineiam essa tradição no Carnaval olindense.

A próxima seção é, portanto, dedicada aos principais conceitos do pensamento foucaultiano que orientam o presente estudo, com ênfase na relação entre tradição e as noções de poder e governo.

\section{PODER, GOVERNO E VERDADE NO PENSAMENTO FOUCAULTIANO}

Para Foucault a constituição histórica da verdade sempre se colocou como uma problemática, cujo entendimento rompe com a compreensão clássica, de uma verdade fixa e transcendente, pois investiga como esta se constitui historicamente mediante: práticas discursivas que estabelecem jogos de regras, seja o modo como esses jogos legitimam estratégias de poder, seja como atuam em práticas de si e processos de subjetivação (CANDIOTTO, 2006). 
Para Foucault (2014b) o exercício de poder dá-se ancorado numa manifestação de verdade, um corpo de conhecimento útil, não necessariamente de natureza científica, mas que permite separar o verdadeiro do falso ou oculto - a esses procedimentos, ele chama aleturgia. Foucault reconhece nas práticas sociais "efeitos de verdade", estratégias pelas quais relações de poder se justificam racionalmente (CANDIOTTO, 2006). Para Foucault (2015, p. 52) haveria uma "economia política da verdade", ou seja, as condições de produção, circulação e consumo dessa verdade estariam profundamente vinculadas a discursos científicos, instituições, poder político, aparelhos de educação, instâncias de controle, debate social, lutas ideológicas etc.

Isto posto, observamos que a questão do governo não se dissocia da verdade. Ao se governar, mobilizam-se verdades sobre a existência que se criam em práticas de produção de conhecimento/verdades e que propiciam o governo dos indivíduos sobre os outros (FIMYAR, 2009). O termo "conduta", para Foucault, expressa justamente esse ato de conduzir a ação de outrem; dessa forma, tendo em vista que o poder opera num campo de possibilidades, é da ordem do governo, sendo este último o ato de conduzir condutas, estruturando, portanto, esse campo de possibilidades no qual a ação de outros se dá. Isso implica a premissa de que o poder só pode operar em condições de liberdade, pois é na liberdade que se colocam tais campos de possibilidade para a ação de indivíduos, em vez que determinações preestabelecidas (FOUCAULT, 2011).

Nesse sentido coloca-se a questão de como obter consentimento de sujeitos livres. Foucault (2014b) afirma que a arte de governar e os jogos de verdade são instâncias indissociáveis: o governo forja-se a partir de uma aleturgia. Os rituais de manifestação de verdade, que extrapolam a dimensão utilitária e calculista do exercício de poder, ampliam suas condições de possibilidade para essas manifestações (FOUCAULT, 2014b). A verdade, portanto, não existe fora do poder nem vice-versa: os regimes de verdade são tipos de discursos que uma sociedade admite como verdadeiros e nele se inserem os mecanismos de determinação da verdade, as técnicas de obtenção da verdade (a exemplo do conhecimento científico) e aqueles a quem competem a veridicção (FOUCAULT, 2015), ou seja, o processo pelo qual discursos considerados verdadeiros sob determinados aspectos emergem e se articulam com um domínio de coisas (REVEL, 2005).

O governo dos homens imbrica-se nessa manifestação de verdade (GORDON, 1991). Para Stival (2016), a relação governo-verdade é análoga à saber-poder. Assim, a governamentalidade deve ser entendida como a junção das técnicas de governo voltadas a si e ao mesmo tempo técnicas exercidas sobre os outros, uma arte de dirigir indivíduos anterior ao Estado, embora este tenha sido governamentalizado na modernidade (CIPAGAUTA, 2006). A criação desse neologismo evoca a necessidade de as práticas de governar serem coerentes com as mentalidades que Ihes são subjacentes, criando-se sujeitos passíveis de se governar através de técnicas que incidem sobre a conduta destes (FIMYAR, 2009).

A governamentalidade é, para Fimyar (2009), uma ferramenta conceitual que permite investigar a racionalidade e a produção de verdade de um governamento, uma vez que, para governar, é necessário que as práticas de governo se alinhem às mentalidades subjacentes, criando sujeitos governáveis. É a noção de governamentalidade que possibilita a Foucault problematizar as formas de ação sobre a conduta de outrem, sem que necessariamente essas formas derivem ou estejam associadas a um aparato estatal (RABINOW; ROSE, 
2006). Nesse sentido, o conceito permite apreender como se governa em consonância com aquilo que é considerado verdade, ao mesmo tempo que, ao governar, produzem-se verdades (FIMYAR, 20109).

No presente estudo, abordaremos a noção de governo no entendimento das práticas organizacionais que se dão na organização do festejo carnavalesco de Olinda. Para a interpretação dos nossos achados, respaldar-nos-emos nos aspectos da obra foucaltiana abordados nesta seção, quais sejam: as instâncias de governo, suas tecnologias políticas, os corpos governados e os mecanismos de resistência, bem como os regimes de verdade subjacentes a esses governos, os processos de legitimação e suas transformações ao longo do período analisado.

\section{PROCEDIMENTOS METODOLÓGICOS}

O presente estudo é de tradição qualitativa e orientação pós-estruturalista. Quanto ao uso da teoria, podemos dizer que se trata de um estudo de caráter parcialmente indutivo, na medida em que utilizamos a teoria como meio de prover o estudo de foco, servindo de lente para interpretação do fenômeno e identificação de categorias empíricas (LEÃO; MELLO; VIEIRA, 2009), sem que estas tenham sido estabelecidas a priori.

Esta investigação apoia-se na contribuição de Michel Foucault. Embora o filósofo tenha desenvolvido sua análise em objetos muito específicos (tais como questões epistemológicas em determinados campos do saber), seus pressupostos são bastante profícuos na compreensão de fenômenos diversos, compreendidos à luz da tríade poder-saber-corpo (THIRY-CHERQUES, 2010). É essa tríade que serve de lente teórica ampla na compreensão do fenômeno analisado, orientando a geração de categorias empíricas.

Ao nos referirmos ao método foucaultiano, não o devemos remeter a uma concepção canônica de método, mas compreendê-lo como uma "techné de investigação" (VEIGA NETO, 2009). Sua Arqueologia do Saber não é propriamente um trabalho metodológico formulado para instrumentalizar pesquisas, mas tão somente uma tentativa de esclarecer o projeto arqueológico empreendido pelo filósofo; no entanto, os conceitos lá sistematizados encarnam um enorme potencial a quaisquer pesquisas que busquem investigar as formações discursivas (NUNES, 2002).

A obra de Foucault costuma ser dividida em duas vertentes: arqueologia, voltada para o entendimento das condições em que os saberes se constituem, por meio das realidades discursivas, utilizando elementos de uma análise de discurso; e genealogia, que enfoca as relações de poder e, posteriormente, o processo de subjetivação, extrapolando as práticas puramente discursivas (DREYFUS; RABINOW, 2011). Ambas compreendem essa teia de saberes e relações de poder como uma constituição histórica (CANDIOTTO, 2006), permitindo investigar limiares e descontinuidades (OLIVEIRA, 2008).

O presente estudo, apesar de compreender quatro décadas do fenômeno, observa-o de forma descontínua. A rigor, não se caracteriza como genealogia ou arqueologia, mas como uma análise de discurso. Tal análise é de inspiração arqueológica, na medida em que vislumbra descortinar as condições de produção de enunciados (OLIVEIRA, 2008), utilizando os conceitos sistematizados por Foucault em Arqueologia do Saber, que corres- 
ponde a uma análise de discurso formulada pelo filósofo (DREYFUS; RABINOW, 2011). O processo analítico opera buscando pertinências entre relações e séries de enunciados que se entrelaçam na constituição dos discursos (THIRY-CHERQUES, 2010). Dessa forma, utilizamos a Análise de Discurso Foucaultiana (ADF) para empreender uma análise cujo objeto inscreve-se numa problemática do poder.

Essa análise de discurso consiste na investigação do sistema geral do qual um discurso faz parte e as condições nas quais este se constitui (FOUCAULT, 2014a). Por discurso, podemos entender uma composição de enunciados cujas regras de funcionamento são comuns, mas cuja análise requer, para além destes, as práticas não discursivas (THIRY-CHERQUES, 2010). A análise de discurso foucaultiana funciona como uma espécie de "grelha" classificatória a partir da qual diferenças e semelhanças são demarcadas, tendo como ponto chegada as formações discursivas (ARAÚJO, 2007).

A coleta de dados vislumbrou a construção de um arquivo, um sistema de enunciados que rege seu aparecimento e fornece-lhe regularidade (FOUCAULT, 2014a). O arquivo é constituído por documentos de uma época, podendo ser de caráter literário ou não (THIRY-CHERQUES, 2010). No presente estudo, ao buscarmos entender o processo organizativo do Carnaval olindense, estabelecemos como ponto de partida o Carnaval de 2016, procedendo a partir daí a um recuo temporal. Fixamos, por outro lado, a década de 1980 como limite desse recuo, com base na pesquisa bibliográfica que orientou a construção do presente estudo e que apontou o término da década de 1970 como uma ruptura com o modelo de palanques e comissões julgadoras para a consolidação do modelo participativo. Dessa forma, analisamos quatro carnavais, que distam 10 anos - o que permitiu uma visão mais ampla das transformações ocorridas, tendo em vista que o presente estudo vislumbrou apreender o Carnaval enquanto processo.

Os documentos utilizados consistem em matérias jornalísticas sobre a cobertura dos quatro carnavais analisados. A opção pelo discurso jornalístico dá-se pelo fato de a mídia produzir um "agendamento de mundo", uma leitura compartilhada da atualidade, exercendo, portanto, um importante papel nos jogos de saber-poder (TUCHERMAN, 2007). Para Foucault (2014c), a opinião, entendida como uma espécie de consciência social, passava pela media - que, por sua vez, estão sujeitos a interesses econômicos e políticos.

Visando manter a unidade dos dados, optamos por acessar os registros de dois jornais do Estado, o Diario de Pernambuco (DP) e o Jornal do Commercio (JC), por serem fontes de notícias em funcionamento regular durante todo o período analisado e em atividade até o presente. Dessa forma, coletamos todas as notícias desses jornais do período de $1^{\circ}$ de janeiro até o primeiro domingo após a Quarta-feira de Cinzas dos respectivos anos: 1986, 1996, 2006 e 2016, momento em que o Carnaval do Estado passa a não figurar nas pautas dos jornais analisados.

Os jornais, de periodicidade diária, foram disponibilizados para consulta no acervo da Biblioteca Pública do Estado de Pernambuco; os volumes foram consultados na íntegra, e digitalizadas todas as matérias sobre o Carnaval de Olinda (não foram considerados informes publicitários, cartas dos leitores, peças publicitárias e seções de opiniões), totalizando 562 documentos, conforme Tabela 1. 
Tabela 1 - Documentos analisados por período e fonte

\begin{tabular}{l|c|c|c|c|c|c|c|c|c|c}
\hline & \multicolumn{2}{|c|}{1986} & \multicolumn{2}{c|}{1996} & \multicolumn{3}{c|}{2006} & \multicolumn{2}{c|}{2016} & \multirow{2}{*}{ TOTAL } \\
\cline { 2 - 10 } & Jan. & Fev. & Jan. & Fev. & Jan. & Fev. & Mar. & Jan. & Fev. & \\
\hline DP & 16 & 30 & 25 & 121 & 28 & 38 & 7 & 25 & 25 & 315 \\
\hline JC & 19 & 21 & 20 & 64 & 16 & 47 & 7 & 28 & 25 & 247 \\
\hline Total & 35 & 61 & 45 & 185 & 44 & 85 & 14 & 53 & 50 & 562 \\
\hline
\end{tabular}

Fonte: Elaboração dos autores

Os documentos foram organizados por ano e analisados com apoio do software NVivo, versão 10. Aqui vale uma ressalva: o software não operou análise de qualquer natureza, a utilização foi para identificar as categorias empíricas no texto, possibilitando a recuperação das informações organizadas conforme essas categorias. Uma vez descrito o procedimento de construção do arquivo, abordaremos agora a análise em si. O Quadro 1 apresenta as categorias que orientaram a análise dos dados, conforme sistematizado em Arqueologia do Saber (FOUCAULT, 2014a):

Quadro 1 - Elementos da Análise de Discurso Foucaultiana (ADF)

\begin{tabular}{|l|l|}
\hline Enunciados & $\begin{array}{l}\text { Elemento indecomponível dos discursos, a menor unidade destes } \\
\text { que pode se relacionar com outras unidades de igual natureza. } \\
\text { Essa unidade não requer uma estrutura proposicional, é tão } \\
\text { somente um conjunto de signos, destituídos ou não dessa estrutu- } \\
\text { ra, a partir do qual se formula ou cria sentido. }\end{array}$ \\
\hline Funções enunciativas & $\begin{array}{l}\text { Modo pelo qual os enunciados enunciam, ou seja, dão a saber, } \\
\text { constituem seu modus operandi, o modo como esse conjunto de } \\
\text { signos existe e se atualiza. }\end{array}$ \\
\hline Regras de formação & $\begin{array}{l}\text { Condições pelas quais as unidades discursivas existem, coexistem, } \\
\text { mantêm-se, modificam-se, rarefazem-se e desaparecem. }\end{array}$ \\
\hline Formações discursivas & $\begin{array}{l}\text { Conjunto de enunciados que apresentam certa regularidade em } \\
\text { seus sistemas de dispersão, suas escolhas temáticas, os objetos e } \\
\text { conceitos de que tratam e seus tipos de enunciação. }\end{array}$ \\
\hline
\end{tabular}

Fonte: Elaboração dos autores

Enquanto o enunciado é o ponto de partida da análise, a formação discursiva é o ponto de chegada, e a análise permite demonstrar como esta se constitui por meio do feixe de relações entre enunciados, funções e regras que convergem. As formações discursivas foram, portanto, o ponto de articulação entre nossos achados e a teoria utilizada.

\section{APRESENTAÇÃO DOS RESULTADOS}

Nesta seção, apresentamos os elementos constitutivos da formação discursiva: os enunciados, as funções enunciativas e as regras de formação discursiva, com a descrição detalhada de como cada elemento é evidenciado empiricamente (Quadro 2). No mapa geral 
de relações (Figura 1), apresentamos a disposição desses elementos, culminando com a formação discursiva identificada, de forma a evidenciar os feixes de relações que a constituem. Visando a facilitar a elaboração dos diagramas e do texto descritivo das formações discursivas, atribuímos códigos aos elementos. Em seguida, apresentamos uma descrição rica e detalhada dos achados, que se constitui de dois elementos: as evidências empíricas que suportam as inferências e a discussão dessas inferências à luz do arcabouço teórico já apresentado.

Quadro 2 - Elementos constitutivos da formação discursiva

\begin{tabular}{|c|c|c|}
\hline \multicolumn{3}{|r|}{ Enunciados } \\
\hline Cód. & Enunciado & Descrição \\
\hline E01 & $\begin{array}{l}\text { O Carnaval promovido pelas } \\
\text { famílias tradicionais de Olinda } \\
\text { é apresentado como o autênti- } \\
\text { co Carnaval olindense }\end{array}$ & $\begin{array}{l}\text { Diz respeito tanto ao reconhecimento da expertise de famílias } \\
\text { olindenses envolvidas com o fazer carnavalesco há várias gerações } \\
\text { quanto ao reconhecimento da participação de outros agentes na } \\
\text { organização do festejo como uma ameaça. }\end{array}$ \\
\hline E02 & $\begin{array}{l}\text { Facções sociais trabalham } \\
\text { no resgate das tradições do } \\
\text { Carnaval olindense }\end{array}$ & $\begin{array}{l}\text { Revela-se defesa do fantasiar-se, do resgate das velhas marchas, } \\
\text { das orquestras de pau e corda, do humor espontâneo, da integração } \\
\text { sem barreira entre os brincantes, alegando a existência de um } \\
\text { processo de profissionalização e conversão do festejo em espetáculo } \\
\text { voltado para o turismo, o que comprometeria a essência do Carna- } \\
\text { val olindense. }\end{array}$ \\
\hline E03 & $\begin{array}{l}\text { Turistas e forasteiros ameaçam } \\
\text { a autenticidade do Carnaval } \\
\text { olindense }\end{array}$ & $\begin{array}{l}\text { Manifesta-se na alegação de que o aumento significativo de turistas } \\
\text { e forasteiros é responsável pelo caráter de espetáculo desprovido } \\
\text { de sentido que o Carnaval de Olinda vem adquirindo ao longo dos } \\
\text { anos, bem como na crença de que esses visitantes usurpam as } \\
\text { manifestações culturais sem trazer qualquer contribuição para a } \\
\text { tradição. }\end{array}$ \\
\hline E04 & $\begin{array}{l}\text { Ritmos não pernambucanos } \\
\text { são desprestigiados no Carna- } \\
\text { val de Olinda }\end{array}$ & $\begin{array}{l}\text { Revela-se na exaltação do frevo, do maracatu e das batucadas como } \\
\text { ritmos genuínos do Carnaval olindense; na menção a medidas que } \\
\text { coíbem a presença dos ritmos não pernambucanos; na associação } \\
\text { desses ritmos à contaminação do festejo etc. }\end{array}$ \\
\hline E05 & $\begin{array}{l}\text { O som eletrônico de } \\
\text { particulares compromete o } \\
\text { funcionamento regular do } \\
\text { Carnaval de rua }\end{array}$ & $\begin{array}{l}\text { Evidencia-se nas menções às medidas disciplinares para conter o } \\
\text { excesso de decibéis e na defesa do som das orquestras em detri- } \\
\text { mento do som eletrônico. }\end{array}$ \\
\hline E06 & $\begin{array}{l}\text { Moradores do Sítio Histórico de } \\
\text { Olinda participam ativamente } \\
\text { da organização do Carnaval } \\
\text { olindense }\end{array}$ & $\begin{array}{l}\text { Manifesta-se no reconhecimento do protagonismo do morador } \\
\text { no processo criativo; na reivindicação pelos moradores do papel } \\
\text { decisório na concepção do festejo; e no reconhecimento do papel } \\
\text { de suporte dado pelo Poder Público à execução do evento efetivada } \\
\text { pelos moradores. }\end{array}$ \\
\hline E07 & $\begin{array}{l}\text { A cultura pop e acontecimentos } \\
\text { midiáticos são referências } \\
\text { criativas para a folia }\end{array}$ & $\begin{array}{l}\text { Revela-se na menção a personagens famosas da teledramaturgia } \\
\text { (e.g.: Viúva Porcina); fatos inusitados no jornalismo (e.g.: "grávida } \\
\text { de Taubaté"); super-heróis e personagens do universo geek (e.g.: } \\
\text { Meninas Superpoderosas, elementos da saga Star Wars); homena- } \\
\text { gens a artistas falecidos (e.g.: Amy Winehouse, David Bowie) etc. }\end{array}$ \\
\hline E08 & $\begin{array}{l}\text { Artistas e foliões promovem } \\
\text { sátira política durante a folia }\end{array}$ & $\begin{array}{l}\text { Evidencia-se tanto na menção ao tema de desfiles em agremiações } \\
\text { que tradicionalmente promovem a sátira quanto na descrição de } \\
\text { fantasias ou performances inspiradas em escândalos políticos, } \\
\text { rixas partidárias, promessas eleitorais, caricaturas de candidatos e } \\
\text { representantes eleitos etc. }\end{array}$ \\
\hline
\end{tabular}




\begin{tabular}{|c|c|c|}
\hline E09 & $\begin{array}{l}\text { Agremiações carnavalescas de } \\
\text { Olinda precisam moldar-se a } \\
\text { um padrão estabelecido como } \\
\text { tradicional para sobreviver }\end{array}$ & $\begin{array}{l}\text { Identifica-se no rechaço às agremiações de menor porte pelas } \\
\text { de maior, no estabelecimento de critérios de elegibilidade para } \\
\text { subvenções do município (geralmente com base na performance das } \\
\text { agremiações tradicionais) e na exigência do respeito aos roteiros e } \\
\text { horários predefinidos. }\end{array}$ \\
\hline E10 & $\begin{array}{l}\text { Agremiações carnavalescas } \\
\text { de Olinda segregam tipos de } \\
\text { foliões }\end{array}$ & $\begin{array}{l}\text { Ocorre na descrição de critérios para se integrar ao desfile oficial de } \\
\text { determinadas agremiações, especificamente em relação a orienta- } \\
\text { ção sexual (blocos que só admitem a inscrição de heterossexuais) e } \\
\text { gênero (blocos que só admitem a participação de homens). }\end{array}$ \\
\hline E11 & $\begin{array}{l}\text { Camarotes representam uma } \\
\text { ameaça ao Carnaval de rua }\end{array}$ & $\begin{array}{l}\text { Manifesta-se nas menções aos conflitos entre o Poder Público e a } \\
\text { sociedade, em que esta última reivindica a proibição de camarotes } \\
\text { no Sítio Histórico, alegando que o Carnaval de Olinda é de rua e que } \\
\text { a instalação de camarotes vai de encontro a isso. }\end{array}$ \\
\hline $\mathrm{E} 12$ & $\begin{array}{l}\text { O Carnaval de Olinda acolhe } \\
\text { toda a diversidade de foliões }\end{array}$ & $\begin{array}{l}\text { Ocorre na defesa da ausência de barreiras para os brincantes } \\
\text { se integrarem ao festejo, propagando um festejo que não impõe } \\
\text { limitações de ordem financeira, geográfica, etária, de gênero, etc.; } \\
\text { na comparação com o Carnaval de outros municípios, marcados } \\
\text { pela normatização; bem como na rejeição a passarelas, comissões } \\
\text { julgadoras, salões e demais elementos que promovam algum tipo de } \\
\text { segregação. }\end{array}$ \\
\hline E13 & $\begin{array}{l}\text { O Carnaval de Olinda é marca- } \\
\text { do pela espontaneidade }\end{array}$ & $\begin{array}{l}\text { Evidencia-se na menção à criação de blocos em meio a brincadeiras } \\
\text { de rua, mudanças de horários e percursos de agremiações sem } \\
\text { planejamento, aos grupos que saem às ruas realizando batuques e } \\
\text { arrastam foliões etc. }\end{array}$ \\
\hline E14 & $\begin{array}{l}\text { Agremiações e personagens } \\
\text { folclóricos do Carnaval de } \\
\text { Olinda são ordenados hierar- } \\
\text { quicamente }\end{array}$ & $\begin{array}{l}\text { Revela-se no reconhecimento de um grupo seleto de agremiações } \\
\text { (seja por longevidade, seja por número e perfil de foliões), que } \\
\text { obtêm maior espaço na imprensa, maior volume de subvenções, } \\
\text { maior interesse em parcerias por parte de marcas anunciantes etc. }\end{array}$ \\
\hline E15 & $\begin{array}{l}\text { O Carnaval de Olinda é } \\
\text { marcado pelo uso intensivo do } \\
\text { espaço público }\end{array}$ & $\begin{array}{l}\text { Ocorre nas alusões ao Carnaval de Olinda como um "carnaval de } \\
\text { rua", desprovido de passarelas ou salões; bem como nas ações para } \\
\text { garantir que as ruas estejam livres de quaisquer obstáculos que } \\
\text { impeçam o fluxo de foliões e agremiações. }\end{array}$ \\
\hline E16 & $\begin{array}{l}\text { O Carnaval congrega a vida } \\
\text { artística olindense }\end{array}$ & $\begin{array}{l}\text { Identifica-se na menção aos artistas plásticos que elaboram alego- } \\
\text { rias e estandartes, bonequeiros envolvidos na confecção de bonecos } \\
\text { gigantes, músicos que atuam como compositores ou em orquestras } \\
\text { etc. }\end{array}$ \\
\hline E17 & $\begin{array}{l}\text { Agremiações promovem causas } \\
\text { durante a folia }\end{array}$ & $\begin{array}{l}\text { Ocorre tanto nas agremiações que são criadas em torno de } \\
\text { determinada causa (e.g.: preservação do Sítio Histórico, defesa da } \\
\text { democracia) quanto naquelas que apoiam determinadas causas } \\
\text { num desfile ou período (e.g.: prevenção de HIV, combate à violência } \\
\text { doméstica). }\end{array}$ \\
\hline E18 & $\begin{array}{l}\text { Em Olinda, atividades } \\
\text { religiosas e carnavalescas } \\
\text { misturam-se }\end{array}$ & $\begin{array}{l}\text { Remete à menção a cerimônias religiosas que visam preparar o } \\
\text { espírito da cidade para a folia, bem como agremiações que desfilam } \\
\text { apresentando elementos religiosos (sejam oriundos de cultos cris- } \\
\text { tãos ou de matriz africana) em suas alegorias ou performances. }\end{array}$ \\
\hline E19 & $\begin{array}{l}\text { O Carnaval de Olinda é marca- } \\
\text { do pela irreverência }\end{array}$ & $\begin{array}{l}\text { Manifesta-se na recorrente menção ao apelo cômico na elaboração } \\
\text { de fantasias; na apropriação de figuras consagradas em fantasias ou } \\
\text { performances satíricas; na apropriação irrestrita do espaço público } \\
\text { etc. }\end{array}$ \\
\hline E20 & $\begin{array}{l}\text { Categorias ocupacionais e } \\
\text { instituições formam agremia- } \\
\text { ções durante o Carnaval }\end{array}$ & $\begin{array}{l}\text { É encontrado na menção aos blocos criados por esses profissionais } \\
\text { ou pelas respectivas instituições a que pertencem (e.g.: Vassourão } \\
\text { de Olinda, bloco formado por profissionais de limpeza urbana do } \\
\text { município; Com Ciência na Cabeça, bloco formado por cientistas). }\end{array}$ \\
\hline
\end{tabular}




\begin{tabular}{|c|c|c|}
\hline E21 & $\begin{array}{l}\text { Carnavalescos e artistas } \\
\text { formam associações para se } \\
\text { fortalecer na organização do } \\
\text { evento }\end{array}$ & $\begin{array}{l}\text { Ocorre nas menções à articulação de músicos, artistas plásticos ou } \\
\text { dirigentes de agremiações no sentido de, junto ao Poder Público, } \\
\text { obter melhores condições de trabalho, negociar percentuais de } \\
\text { subvenções, prospectar patrocinadores, discutir o formato do festejo } \\
\text { etc. }\end{array}$ \\
\hline E22 & $\begin{array}{l}\text { O Carnaval de Olinda segrega } \\
\text { foliões genéricos }\end{array}$ & $\begin{array}{l}\text { Revela-se tanto na menção às casas patrocinadas, em que os } \\
\text { patrocinadores selecionam artistas e influenciadores para participar, } \\
\text { como os camarotes para os quais os participantes pagam um valor, } \\
\text { geralmente restritivo, e têm acesso em um ou mais dias do festejo. }\end{array}$ \\
\hline E23 & $\begin{array}{l}\text { Bonecos gigantes exaltam } \\
\text { personalidades no Carnaval de } \\
\text { Olinda }\end{array}$ & $\begin{array}{l}\text { Evidencia-se na menção aos novos integrantes do tradicional desfile } \\
\text { de bonecos gigantes, que ocorre às terças-feiras, bem como as } \\
\text { iniciativas de foliões em homenagear personalidades dedicando-Ihe } \\
\text { um boneco gigante. }\end{array}$ \\
\hline E24 & $\begin{array}{l}\text { Carnavalescos desenvolvem } \\
\text { mecanismos de arrecadação } \\
\text { para financiar os desfiles }\end{array}$ & $\begin{array}{l}\text { Ocorre revelando as ações empreendidas pelos dirigentes para suprin } \\
\text { a insuficiência das subvenções concedidas pela municipalidade, } \\
\text { bem como para as demandas advindas do aumento de porte das } \\
\text { agremiações. }\end{array}$ \\
\hline E25 & $\begin{array}{l}\text { O Carnaval de Olinda possui } \\
\text { uma duração ampliada }\end{array}$ & $\begin{array}{l}\text { Manifesta-se tanto no reconhecimento da existência de um calen- } \\
\text { dário oficial planejado pelo Poder Público mais amplo que o tríduo } \\
\text { momesco, contemplando as prévias como eventos integrantes do } \\
\text { ciclo carnavalesco, quanto na legitimidade da ação de brincantes e/ } \\
\text { ou agremiações que extrapolam esse calendário oficial, saindo às } \\
\text { ruas cada vez mais cedo e se retirando cada vez mais tarde. }\end{array}$ \\
\hline E26 & $\begin{array}{l}\text { Agremiações mudam suas } \\
\text { rotinas para se beneficiarem de } \\
\text { políticas públicas e investimen- } \\
\text { tos privados }\end{array}$ & $\begin{array}{l}\text { Revela-se na menção a situações em que agremiações quebram } \\
\text { protocolos (tais como desfilar exclusivamente no Sítio Histórico ou } \\
\text { em data fixa) para receber determinada premiação ou figurar em } \\
\text { evento privado. }\end{array}$ \\
\hline \multicolumn{3}{|r|}{ Funções enunciativas } \\
\hline Cód. & Função & Descrição \\
\hline F01 & $\begin{array}{l}\text { Legitimar um modelo de } \\
\text { autenticidade do festejo }\end{array}$ & $\begin{array}{l}\text { Evidencia-se nos enunciados que descredenciam manifestações } \\
\text { advindas de grupos não dominantes; naqueles que reivindicam } \\
\text { a chancela de famílias tradicionais olindenses nas agremiações; } \\
\text { naqueles que determinam perfis de foliões, ritmos, práticas e espa- } \\
\text { ços legítimos de folia, bem como os que questionam esses status. }\end{array}$ \\
\hline F02 & $\begin{array}{l}\text { Atestar participação popular na } \\
\text { organização do festejo }\end{array}$ & $\begin{array}{l}\text { Revela-se nos enunciados que reconhecem o papel criativo da popu- } \\
\text { lação, bem como atribui-Ihe poder de negociar ou mesmo deliberar. }\end{array}$ \\
\hline F03 & $\begin{array}{l}\text { Evidenciar aspectos da vida } \\
\text { cotidiana que se mesclam à } \\
\text { folia }\end{array}$ & $\begin{array}{l}\text { Está presente nos enunciados que ressaltam como a política, as } \\
\text { demandas sociais, os aspectos religiosos, as referências midiáticas } \\
\text { etc. fazem-se presentes nos processos criativos e organizativos do } \\
\text { Carnaval de Olinda. }\end{array}$ \\
\hline F04 & $\begin{array}{l}\text { Descrever processos organiza- } \\
\text { tivos envolvidos na concepção } \\
\text { do evento }\end{array}$ & $\begin{array}{l}\text { Revela-se nos enunciados de cunho descritivo que apontam meca- } \\
\text { nismos de organização, negociação e normatização realizados por } \\
\text { carnavalescos, dirigentes de agremiações e foliões. }\end{array}$ \\
\hline F05 & $\begin{array}{l}\text { Delinear características organi- } \\
\text { zativas do evento }\end{array}$ & $\begin{array}{l}\text { Faz-se presente nos enunciados que descrevem traços distintivos } \\
\text { dessa forma de organizar (irreverência, improviso, espontaneidade), } \\
\text { evocam aspectos hierárquicos e normativos, bem como revelam } \\
\text { a relação dos agentes com o espaço público e a vida cultural da } \\
\text { cidade. }\end{array}$ \\
\hline \multicolumn{3}{|r|}{ Regras de formação } \\
\hline Cód. & Regra & Descrição \\
\hline R1 & Demarcação de fronteiras & $\begin{array}{l}\text { Aponta a existência de critérios de pertencimento, pelos quais } \\
\text { foliões são habilitados ou impedidos de se integrar em determinadas } \\
\text { manifestações carnavalescas. }\end{array}$ \\
\hline
\end{tabular}




\begin{tabular}{|l|l|l|}
\hline R2 & Configuração do festejo & $\begin{array}{l}\text { Revela a premissa de que o Carnaval de Olinda tem sua feição } \\
\text { marcada pela participação popular, pela preservação de tradições } \\
\text { ao longo de décadas e pela imbricação com a vida artística e } \\
\text { religiosa da cidade. }\end{array}$ \\
\hline R3 & Participação popular & $\begin{array}{l}\text { Revela o engajamento da população nos processos de decisão e } \\
\text { execução do festejo, reconhecendo esse processo participativo como } \\
\text { uma característica do Carnaval de Olinda preservada ao longo das } \\
\text { décadas. }\end{array}$ \\
\hline
\end{tabular}

Fonte: Elaboração dos autores

Conforme mencionamos anteriormente, a relação entre os elementos constitutivos, acima apresentados, culmina na formação discursiva. A Figura 1 ilustra como eles elementos se relacionam e constituem tal formação.

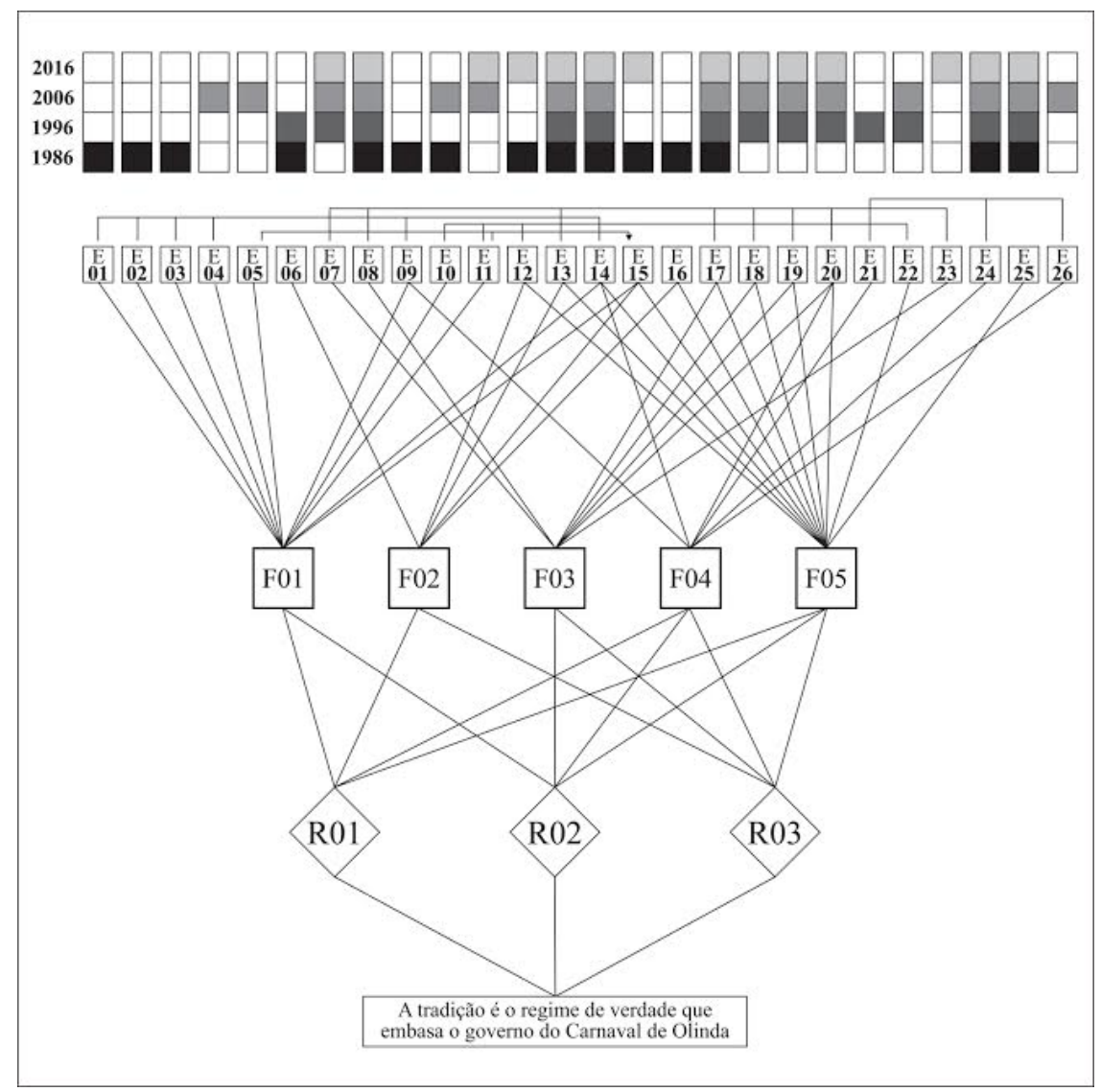

Figura 1 - Elementos que constituem a formação discursiva

O feixe de relações acima ilustrado aponta para a formação discursiva "A tradição é o regime de verdade que embasa o governo do Carnaval de Olinda", repousando na tradição um ideal de autenticidade pelo qual práticas de governo legitimam e são legitimadas. Esta formação discursiva indica a existência de uma tradição consolidada ao longo das décadas, inserida em lutas e negociações de poder que envolvem tanto a preservação dessas 
práticas quanto o questionamento delas. Essa concepção de tradição permeia não só as manifestações culturais carnavalescas, mas também os "bastidores" dessas manifestações, o processo pelo qual os agentes envolvidos se organizam e produzem o festejo, o que pressupõe aspectos hierárquicos e papéis estratégicos (e por vezes privilegiados), nos quais a participação do povo é a espinha dorsal.

No que diz respeito aos elementos constitutivos oriundos da análise de discurso, a formação é composta de três regras, cinco funções e 26 enunciados. Podemos observar que a regra de formação que remete à demarcação de fronteiras (R01) liga-se a todas as funções da formação discursiva, exceto àquela que diz respeito à relação entre vida cotidiana e folia (F03). Os enunciados que constituem esse feixe de relações têm uma incidência significativamente maior na década de 1980 , sobretudo aqueles que se referem às práticas de legitimação. Dentre estes, destacamos os que remetem ao protagonismo dos moradores e dos artistas locais na organização do festejo e na preservação de um ideal de tradição, sendo o pertencimento um mecanismo de estabelecimento de fronteiras - tais enunciados não se repetem nas décadas subsequentes, muito embora nas últimas décadas analisadas alguns elementos da tradição voltem a incidir como forma de resistência às mudanças ocorridas no festejo (a exemplo da rejeição ao som eletrônico e aos camarotes). Isso remete claramente à ruptura operada no final da década de 1970 e à instauração de um novo Carnaval, cuja identidade reside na oposição ao modelo de espetáculo. Os aspectos referentes às demais funções ocorrem de maneira estável ao longo das décadas.

Quanto à configuração do festejo (R2), que se liga a todas as funções exceto àquela que afirma a participação popular (F02), observamos que, no que diz respeito às práticas organizativas (F04) e ao modo de se organizar (F05) concentram-se ora na década de 1980, ora nas décadas subsequentes, demarcando a década de 1990 como um ponto de ruptura no que diz respeito ao processo de profissionalização do fazer carnavalesco, indicando a existência de práticas mais estruturadas a partir desse período.

Já a participação popular (R3) liga-se a todas as funções desta formação, exceto à de legitimação de um modelo de autenticidade (FO1). No entanto, embora a incidência dos enunciados que constituem este feixe de relações seja relativamente estável ao longo das décadas analisadas, observamos que na década de 1980 enfatiza-se a participação na concepção do festejo, enquanto os enunciados que refletem o engajamento no folguedo ocorrem nas quatro décadas sem qualquer destaque significativo.

À luz do pensamento foucaultiano, essa formação evoca um regime de verdade ancorado na noção de tradição. Sob esse regime de verdade, a noção de autenticidade funciona como mecanismo de legitimação ou deslegitimação de práticas do fazer carnavalesco, que, por sua vez, orienta tecnologias disciplinares operantes nos foliões e participantes das manifestações carnavalescas, sobretudo pelos processos de classificação e exclusão.

Essa formação revela fortemente a noção de governo enquanto condução de conduta, sem clara associação à figura do Estado. Ao examinarmos as práticas sociais, observamos como estas incorporam mecanismos estratégicos que justificam racionalmente o exercício de poder, cujos efeitos seriam as técnicas de governo de pessoas. Na presente formação discursiva, a noção de tradição (e o consequente recurso ao passado) justifica que determinados grupos se incumbam de governar outros, operando mecanismos de classifica- 
ção e adestramento. Na passagem a seguir, exemplificaremos como o aspecto da tradição como regime de verdade se revela em nossos achados.

E conta que a tradição carnavalesca de lá vem desde o começo do século. "Isso se faz notar nas mais autênticas agremiações do Carnaval de Olinda. É como uma espécie de árvore genealógica que estende suas raízes através dos tempos nas famílias dos verdadeiros foliões, como aconteceu com o clã Gregório Lobo ${ }^{1}$. [...] Dessa maneira, são três gerações fazendo e preservando a pureza do Carnaval de Olinda." (DP, jan. 1986, n. 02)

Na passagem, extraída da matéria Em Olinda, quem faz o Carnaval é o povo, podemos observar como a ideia de tradição é evocada pela analogia a uma árvore genealógica. O século XX figura como uma demarcação temporal dessa tradição, fortemente ancorada na família. Ao supor a "pureza" do Carnaval promovido por essas famílias, apenas indivíduos que têm o status do pertencimento a famílias tradicionais do Sítio Histórico de Olinda possuiriam a expertise para organizar o festejo (E01), o que visa legitimar esse fazer carnavalesco em detrimento de outros (F01). Por sua vez, a relação entre essa pressuposição de pureza e o intuito de promovê-la como duas manifestações legítimas inscrevem-se tanto num processo de atribuição de uma identidade, uma feição ao festejo (R2), marcada fortemente pela chancela dessas famílias, quanto de estabelecimento de fronteiras, com seus mecanismos de inclusão e exclusão (R1). Aqui observamos a existência de "carnavalescos legítimos" - cuja legitimidade advém tanto de laços sanguíneos quanto de uma expertise carnavalesca acumulada ao longo dos anos - operando relações de poder articuladas no regime de verdade da tradição.

Por sua vez, a tradição vale-se da noção de autenticidade para legitimar as práticas que emergem do corpo social. À medida que o festejo assume dimensões cada vez maiores, quanto ao número de foliões e agremiações, os grupos que buscam "governar" a organização do Carnaval olindense operam mecanismos de poder sob a premissa da autenticidade. Se o regime de verdade que articula as práticas organizativas do Carnaval olindense evoca um ideal de "pureza", o processo de legitimação dos participantes e daquilo que é proibido ou permitido fazer emanam dessa premissa, apontando para a questão da autenticidade. Podemos observar no exemplo abaixo como essa legitimação é operada na relação entre agremiações:

Apesar da crise - afirmou -, as agremiações que mantêm a tradição do horário do desfile, dia, fantasia convencional, roteiro e outras providências continuam firmes no Carnaval de Olinda e isso contribui para seu crescimento. Na opinião de Cabela, não é preciso ser agremiação secular nos festejos carnavalescos da cidade para obedecer essas regras do tradicionalismo, pois o bloco Eu Acho É Pouco ${ }^{2}$ vem mantendo o respeito à tradição e desfila nos horários e

1. À família Gregório Lobo é creditada a fundação de antigas e tradicionais agremiações, prática que se teria ramificado ao longo das gerações, dando origem ao clube Lenhadores, à escola de samba Preto Velho e à troça infantil John Travolta, ainda em atividade, bem como outras agremiações que encerraram suas atividades ou ramificaram-se em dissidências.

2. O Grêmio Lítero Recreativo Cultural Misto Eu Acho É Pouco foi fundado no ano de 1976, em plena ditatura, com a proposta de satirizar a vida política do país. Seu desfile conta com um enorme dragão manipulado 
roteiro elaborado pelos seus fundadores, não sai do seu "habitat" - o Sítio Histórico - mesmo que Ihe seja oferecida qualquer quantia pelos promotores de grandes eventos fora de Olinda (DP, jan. 1986, n. 17)

A passagem corresponde à fala do então diretor de uma das mais "tradicionais" troças carnavalescas, a Ceroula de Olinda ${ }^{3}$, apresentado na matéria intitulada Cabela defende a preservação do antigo Carnaval como "uma das lideranças do Carnaval Olindense". De uma posição privilegiada de fala conferida pelo seu papel de liderança, ele estabelece parâmetros pelos quais uma agremiação deve ser reconhecida e legitimada no festejo. Sua fala evidencia a obrigatoriedade de moldar-se a um padrão de desfile estabelecido como tradicional como requisito para sua longevidade (E09), o que aponta para a necessidade de descrever como uma agremiação deve proceder (F04) para ser considerada autêntica (F01). Segundo ele, a base dessa legitimidade encontra-se em replicar os padrões organizativos já consagrados pelas agremiações tradicionais. Ao ressalvar que "[...] ser uma agremiação secular nos festejos carnavalescos" não é condição sine qua non para o reconhecimento dessa agremiação, a fala revela a existência de uma hierarquia entre as manifestações carnavalescas (E14), que aponta para a demarcação de posições claras de poder como um aspecto inerente à cultura dessa organização (F05), ao mesmo tempo que descreve os requisitos necessários (FO4) para o reconhecimento de autenticidade (F01). Essa inserção de práticas organizativas num ideal de autenticidade revela um processo de evocação das singularidades do festejo (R2).

Nesse exemplo, o carnavalesco possui a prerrogativa de normatizar com base nesse regime de verdade. Ao mesmo tempo que a fala dessa liderança reforça a tradição que Ihe confere poder, ele se vale do poder conferido por essa tradição para atribuir o status de autenticidade às práticas. Tais "líderes" têm espaço privilegiado nos meios de comunicação, o que não só amplifica sua voz e seu poder de regulamentação e reforça sua posição de liderança.

A ideia de que essas lideranças operam não só pela via da repressão, mas sobretudo pelo processo de legitimação fundamentado na autenticidade, pode ser evidenciada no modo como a noção de participação popular articula diversas práticas, tanto no âmbito da produção quanto no da experiência do festejo. Na matéria jornalística Olinda entra em ritmo cósmico, essa condição de festejo participativo é mencionada como uma consequência da abolição do modelo de palanques e passarelas e a essa característica é atribuído o sucesso que, segundo a matéria, o Carnaval de Olinda obtivera com o término da década de 1970, quando o modelo então vigente caíra em desuso:

A partir de 1977, o Carnaval olindense começou a atrair foliões e turistas em consequência das inovações introduzidas pela Prefeitura de Olinda, abolindo as passarelas, os palanques e os cordões de isolamento, que se tornavam

por pessoas e, atualmente, com um dragão-filhote, de chupeta, que conduz os foliões-mirins que desfilam na vertente infantil da agremiação, Eu Acho É Pouquinho. Politizado desde a fundação, o Eu Acho É Pouco tem participado de diversos atos fora do período momesco a favor da democracia, como marchas e passeadas.

3. Fundada em janeiro de 1962, a Troça Carnavalesca Ceroula de Olinda é uma dissidência da troça Pijama, e sua brincadeira se caracterizava pelo acesso exclusivo de homens no cordão oficial, embora atualmente as mulheres participem da brincadeira. Possui uma das mais respeitadas orquestras do Carnaval de Olinda. 
um obstáculo entre as agremiações e o público que comparecia ao mais animado Carnaval de rua que se realiza no País para se divertir à vontade. Com as medidas adotadas, o Carnaval de Olinda tornou-se mais participativo, porquanto as agremiações, juntamente com os moradores, artistas, artesãos e outros, passaram a realizar o mais popular evento do calendário turístico da cidade, cabendo à Prefeitura apenas um trabalho infraestrutural: iluminação, circulação de veículos, material para ornamentação, ajuda financeira dentro das possibilidades do erário municipal e outras ações da alçada do Poder Público. A decoração da cidade passou a ser feita pelos moradores e artistas Olindenses (JC, fev. 1986, n. 12)

Na passagem, os moradores do Sítio Histórico figuram como agentes importantes (E06), notadamente os artistas que lá habitam (E16). Essa transposição da vida artística de Olinda para o fazer carnavalesco revela como o cotidiano e a folia se misturam (FO3). Os moradores e os artistas locais exercem um protagonismo na organização desse festejo (F04). A experiência da folia, por sua vez, dá-se em espaço público (E15), no que se propaga a ausência de barreiras físicas. Assim, observamos um intuito de reconhecer essa participação como uma prática organizativa típica (F02), ao mesmo tempo que enfatiza o uso do espaço público como um modo de se organizar (F05). Esse protagonismo dos moradores e artistas na organização, bem como a ausência de barreiras no espaço público, apontam para a ideia de participação popular (R3), que perpassa tanto a produção quanto a experiência do festejo. Essa participação mostra-se um aspecto central desse paradigma que se instaura após a ruptura com o modelo anterior, considerado segregador, tendo em vista que, ao folião não desfilante, cabia unicamente o status de espectador. Por outro lado, ao mesmo tempo que a matéria coloca a Administração Pública numa posição de mero apoio (utiliza a palavra "ajuda" para se referir às subvenções), afirmando terem os artistas e moradores do Sítio Histórico autonomia nesse processo, enfatiza o papel decisório da Prefeitura, pois partira dela a implantação do modelo participativo.

Essa noção de participação nos remete à ideia de classificação e segregação como técnicas que são operadas no corpo social. Isso porque, é válido ressaltar, a participação não se dá de forma livre e irrestrita. Destacam-se nesse processo os moradores do Sítio Histórico, sobretudo aqueles que pertencem à vida artística olindense. Essas lideranças, por sua vez, operam tecnologias de poder no sentido da manutenção de certos status bem como na consecução de seus objetivos. Nesse sentido, podemos observar a operação de tecnologias disciplinares, que partem de práticas classificatórias (gênero, orientação sexual, pertencimento a determinada família, habitação etc.) para estabelecer uma rede de poder que, ao classificar, normatiza e segrega. Dessa forma, os agentes criam e/ou ocupam espaços físicos ou imaginários de pertencimento, sejam demarcados por normas explícitas, sejam por um acordo tácito entre os participantes e não participantes, ancorados no regime de verdade, como podemos observar no exemplo abaixo:

E enumera uma série de características que fazem do Carnaval de Olinda diferente de todos os outros. É um carnaval sem passarelas, sem comissão julgadora, sem palanque oficial, onde todo mundo brinca. 0 próprio povo decora das ruas da C. Alta. A existência de blocos como As "Virgens de Bairro 
Novo"4, onde não desfilam mulheres, só homens, mas vestidos de calcinhas, sutiãs, saias, blusas, saltos altos, muito batom, carmim na cara. Com um detalhe: para desfilar nas "Virgens" tem que ser homem com $\mathrm{H}$ maiúsculo, homossexual é banido (DP, jan. 1986, n. 02).

Esse trecho data da década de 1980 e ilustra como a construção da identidade do Carnaval de Olinda passa por um processo de demarcação de fronteiras, na medida em que, ao enumerar as características que o tornam "diferente de todos os outros", a dimensão da participação e seus respectivos mecanismos de inclusão e exclusão tornam-se bastante evidentes. Ao rechaçar as passarelas e as comissões julgadoras, percebemos novamente 0 uso intensivo do espaço público (E15) como uma prática legitimada (F01) no Carnaval olindense e um modo de se organizar e experienciar o festejo (F05). Por sua vez, ao afirmar essa ausência de barreiras de ordem física e burocrática (comissões julgadoras), observamos a proposta de um festejo que acolhe (E12), o que mais uma vez insere a participação popular (F02) no modus operandi do festejo (F05). O trecho também evidencia a participação popular não apenas no direito de integrar livremente a folia, mas na preparação do festejo, ao reconhecer o papel do povo na decoração das ruas (E06), no intuito de atestá-la como traço do festejo (F02). Por outro lado, se é verdade que o espaço público se mostra aberto à integração, não impondo barreiras ao acesso, as agremiações seguem seus próprios parâmetros. Dessa forma, revela-se a existência de critérios para acolher categorias de foliões ou impedir-Ihes o acesso (E10), o que se revela na heterossexualidade compulsória aos participantes do bloco As Virgens de Bairro Novo, legitimando a prática de desfilar travestido como um direito exclusivo de homens cisgêneros e heterossexuais (F01), ao mesmo tempo que revela a prática da normatividade na organização de agremiações (F04). Ao estabelecer que o Carnaval em Olinda é uma construção participativa, mas essa participação segue critérios que operam mecanismos de inclusão e exclusão, temos uma demarcação de fronteiras $(R 1)$. Esse processo de incluir e excluir, por sua vez, está atrelado à ideia de uma tradição e, neste caso específico, ao se inserir numa problemática de orientação sexual, remete à noção de normalização.

Por outro lado, é válido ressaltar que a normalização, que está intimamente ligada à produção biopolítica, é um processo dinâmico, cujas práticas vão-se modificando ao longo da história, à medida que diagramas de forças se reconfiguram. As questões de gênero e orientação sexual são bastante elucidativas desse processo. Enquanto na primeira década analisada existia a proibição expressa do acesso de homossexuais a determinadas manifestações, sob a alegação de que aquilo feria a família tradicional, na última década foi criada pelo próprio poder público a "passarela da diversidade", um espaço de folia dedicado ao público LGBT. Embora, em ambos os casos, operem processos classificatórios típicos do disciplinamento, a condição de LGBT perde, ao longo das décadas, o status de ameaça à tradição - ou pelo menos tem esse status atenuado à medida que lutas sociais se instauram nesse sentido e questionam a vigência de certas verdades.

4. As Virgens de Bairro Novo desfilam no domingo que antecede o Carnaval, quando homens se vestem de mulher e encarnam personagens. A brincadeira ocorre na orla (e não no Sítio Histórico) e conta com uma comissão julgadora que premia as fantasias e performances dos desfilantes inscritos em diversas categorias. Fundada em 1953, a agremiação foi eleita abertura oficial do Carnaval de Olinda pelo Decreto n 02/1981, pelo então Prefeito Germano Coelho. 
Dessa forma, observamos que novos campos de possibilidade se estabelecem ao longo das décadas analisadas, como a imagem do turista, que figura como uma ameaça à tradição, sendo posteriormente convertida em audiência para o festejo e indicador de sua magnitude.

O novo bloco, prossegue, pretende resgatar a tradição das agremiações participantes que vão às ruas com muito humor, alegria, descontração, mas sobretudo com conteúdo político. Por outro lado, acrescenta, o Sai na Marra ${ }^{5}$ procurará oxigenar o Carnaval de Olinda com novos ares de folia, rompendo o esquema alegorista-passarelesco que tenta profissionalizar o Carnaval levando em consideração apenas o turismo - ameaçando transformar o melhor Carnaval do mundo numa missa profana (JC, fev. 1986, n. 15).

O exemplo acima evidencia a resistência à ideia de tradição defendida pelas já mencionadas lideranças carnavalescas. Nele, a tradição é descrita como a prática da irreverência (E11) - entendida aqui como a ruptura intencional de protocolos sociais -; da espontaneidade (E13) e da sátira política (E08), bem como pelo livre uso do espaço público (E15), opondo-se aos desfiles das grandes agremiações com alegorias e fantasias ricamente ornamentadas, reduzindo a experiência carnavalesca a um esquema classificatório (desfilante versus audiência), visando converter essa experiência num espetáculo com finalidades turísticas. As características apontadas visam legitimar outro modelo de autenticidade que não o defendido pelas lideranças (F01). Enquanto a espontaneidade e o livre uso do espaço público descrevem o que caracteriza esse modo de operar a tradição (F05), a sátira política indica um aspecto do cotidiano que nela se revela (F03). Já a ruptura com as práticas consagradas pelas agremiações tradicionais indica processos pelos quais essa resistência se organiza (F04). Essa organização da resistência sob um outro padrão de pensar a tradição aponta para uma tentativa de configuração do festejo (R2), divergente da configuração hegemônica. É importante observar como nessa passagem outras condições de possibilidade são inseridas no regime da tradição, revelando a existência de grupos no interior das lideranças carnavalescas para os quais a manifestação de verdade vigente não é legitimada, o que revela outras relações de força nesse diagrama de poder.

Como vimos, a tradição que constitui esse regime de verdade e orienta essas práticas de governo atua sobretudo no corpo social, estabelecendo práticas de organizar e vivenciar a experiência carnavalesca, que modificam suas condições de verdade e possibilidade ao longo dos anos, articulando-se, ainda assim, nessa noção de tradição. Nesta formação, observamos as tensões poder-resistência numa dinâmica de governo que não se insere num contexto de Estado, embora este perpasse tais relações.

\section{CONSIDERAÇÕES FINAIS}

Tendo em vista a abordagem de poder que orientou a presente análise, pudemos observar que o Carnaval de Olinda revela práticas de governo não só circunscritas à ação da

5. A Troça Carnavalesca Mista Sai na Marra, vinculada ao PCdoB, foi fundada em 1986 e defende, desde a sua fundação, uma folia pública e agregadora, sem restrições de qualquer natureza. Os desfiles usam como recurso a irreverência e promovem a sátira política, e seu hino associa Carnaval a revolução. 
Administração Pública (notadamente municipal), como, sobretudo, na condição de folguedo popular, sob a direção de grupos ligados propriamente às manifestações culturais típicas do período momesco.

O estudo evidencia que as práticas de governo se inserem em todas as dimensões do festejo. Ressaltando que governar pressupõe dispor as coisas e indivíduos às finalidades a que se propõem, podemos dizer que organização pressupõe governo da conduta de outrem, seja esse governo praticado pelos indivíduos ou circunscrito às instituições. Nesse sentido, a governamentalidade inerente ao Carnaval é um aspecto que se mostra desde práticas de organização menos estruturadas até aquelas altamente protocolares.

Nesse sentido, a questão da verdade revelou-se em nossos achados como um aspecto indissociável dessas práticas, na medida em que demarcam as condições de possibilidade para o exercício desse governo e que repousam num ideal de tradição. Essa tradição, enquanto regime de verdade, estabelece os limites dentro dos quais as práticas de organização e de folia são legitimadas em detrimento de outras, bem como dispõe as condições de veridicção nas quais alguns indivíduos, grupos ou organizações são habilitados a conduzir a conduta de outros.

O Carnaval de Olinda, apesar de inserir-se na agenda dos megaeventos carnavalescos do país e assimilar a lógica subjacente a esses eventos, autoproclama-se um Carnaval participativo, do povo e agregador, e por esses traços define sua singularidade. Apesar de ocorrer efetivamente no espaço público e ser livre de restrições de acesso (como abadás ou ingressos), observamos como o Carnaval de Olinda legitima seu ideal de tradição e quais as condições de possibilidade desse regime de verdade. Nesse sentido, embora as barreiras físicas de acesso não se coloquem tão claramente, existem mecanismos de segregação que operam sobre os corpos, seja pela posse de recursos que lhes permita ingressar ou não numa agremiação, seja pelas condutas que vão de encontro ao regime de verdade vigente. No tocante à organização do evento, essa questão da participação torna-se ainda mais problemática, na medida em que pressupõe uma aderência ao regime da tradição, aos elementos consagrados pelos grupos que, em virtude desse regime de verdade, ocupam uma posição legítima de governo, ainda que esse regime venha incluindo novos objetos e condições de possibilidade ao longo das décadas.

O surgimento de novas condições de possibilidade remete às tensões legitimidade-resistência que delineiam esse regime de verdade e que, com o passar dos anos, vão nele inserindo novos objetos. A década de 1980, como já mencionamos, foi considerada ponto de chegada do nosso recuo temporal tendo em vista que em seu limiar se instalaram as modificações que se inserem no projeto identitário do que hoje conhecemos como o Carnaval de Olinda. A ruptura com o modelo de passarelas e a consagração da rua como espaço legítimo e irrestrito de folia indica a existência de um projeto, sobretudo da gestão pública municipal, de consolidar esse Carnaval na agenda dos grandes carnavais e demarcar sua identidade em relação aos demais. Nesse sentido, em nossos achados, os enunciados oriundos de documentos dessa década apontam sobretudo para a tentativa de consolidação de um ideal de tradição, que se assenta nas noções de pureza, autenticidade, participação e fidelidade às raízes. Ao mesmo tempo, esses achados revelam a resistência de grupos cujas vozes são minimizadas ou suprimidas nesse processo de construção de um modelo de autenticidade. 
O recorte temporal, que possibilitou um olhar sobre quatro décadas, apontou também como a resistência oriunda das vozes suprimidas ou minimizadas possibilitou a inserção de novos objetos nesse regime de verdade, revelando que, a despeito da persistência da ideia de tradição enquanto regime, novos rituais de manifestação de verdade, aleturgias, emergem e incluem novas condições de possibilidade para o governo de sujeitos livres.

Os aspectos aqui discutidos evidenciam que o Carnaval de Olinda, sob o discurso da desordem e espontaneidade, apresenta uma complexa configuração organizacional que vislumbra dar conta da magnitude cada vez maior do festejo. Essa configuração é perpassada por relações de poder as mais diversas, que operam sobre os corpos e que emanam de várias instâncias, que não apenas as organizações formais. Nesse sentido, podemos dizer que o Carnaval é atravessado por tecnologias disciplinares. A proclamada espontaneidade é, então, inscrita nesse processo como um conjunto de possibilidades dentro das quais se dão as práticas de governo.

As questões organizacionais aqui discutidas demonstram que o Carnaval de Olinda constitui um objeto complexo de estudo das relações de poder, bem como das condições de veridicção que sustentam e são sustentadas no governo desse folguedo. Como limitação desta investigação, citamos o acesso a um único tipo de discurso, o do jornalismo impresso. A opção por esse tipo de dado deve-se à característica polifônica do discurso jornalístico, bem como ao fato de ser este o único meio que possibilite a ampla cobertura de todo o intervalo estudado. Para minimizar tal limitação, optamos por dois grandes jornais, de forma a triangular os discursos. A relevância deste estudo justifica-se não só pelo crescente interesse que o Carnaval, enquanto fenômeno organizacional, tem despertado na academia, mas também pelos desdobramentos que ele enseja: compreender o Carnaval sob o prisma das relações de poder e à luz do pensamento foucaultiano permite compreender várias instâncias dessa complexa configuração, tais como a relação Estado-sociedade civil, folião-agremiação, agremiação-Estado, entre outras. Por outro lado, cada vez mais orientado pela dinâmica dos megaeventos, o Carnaval de Olinda encontra-se tensionado, de um lado, pelo discurso da tradição e suas consequentes redes de poder e resistência e, por outro, pelo discurso do mercado e seu imperativo do desempenho.

\section{AGRADECIMENTOS}

Agradecemos à Fundação de Amparo à Ciência e Tecnologia do Estado de Pernambuco (Facepe) pelo apoio na realização do presente trabalho.

\section{REFERÊNCIAS}

ARAÚJO, I. L. Formação discursiva como conceito chave para a arqueogenealogia de Foucault. Revista Atlas, Dossiê Foucault, n. 3, dez. 2003-mar. 2007, p. 1-24.

ARAÚJO, R. C. B. de. Festas: máscaras do tempo. Entrudo, mascarada e frevo no Carnaval do Recife. Recife: Fundação de Cultura Cidade do Recife, 1996.

ATAÍDE, J. Olinda, Carnaval e povo: 1900-1981. Olinda: Fundação Centro de Preservação dos Sítios Históricos de Olinda: 1982. 
BURKE, P. 0 que é história cultural? Rio de Janeiro: Jorge Zahar, 2005.

CANDIOTTO, C. Foucault: uma história crítica da verdade. Trans/Form/Ação, São Paulo, v. 29, n. 2, p. 65-78, 2006.

CATENACCI, V. Cultura popular: entre a tradição e a transformação. São Paulo em perspectiva, v. 15, n.2, p. 28-35, 2001.

CIPAGAUTA, H. C. Foucault y el sujeto político: ética del cuidado de sí. Bogotá: Siglo del Hombre Editores, 2006.

DaMATTA, R. Carnaval, malandros e heróis: para uma sociologia do dilema brasileiro. 6.ed. Rio de Janeiro: Rocco, 1997.

DREYFUS, H. L.; RABINOW, P. Michel Foucault, uma trajetória filosófica: para além do estruturalismo e da hermenêutica. Rio de Janeiro: Forense, 2011.

FIMYAR, O. Governamentalidade como ferramenta conceitual na pesquisa de políticas educacionais. Educação \& Realidade, v. 34, n. 2, p. 35-56, 2009.

FOUCAULT, M. Microfísica do poder. 2.ed. Rio de Janeiro: Paz e Terra, 2015.

Arqueologia do saber. 8.ed. Rio de Janeiro: Forense Universitária, 2014a.

Do governo dos vivos: curso no Collège de France (1979-1980). São Paulo: Martins Fontes, 2014b.

. História da Sexualidade: a vontade de saber. São Paulo: Paz e Terra, 2014c.

. "O sujeito e o poder". In: DREYFUS, H. L.; RABINOW, P. Michel Foucault, uma trajetória filosófica: para além do estruturalismo e da hermenêutica. Rio de Janeiro: Forense, 2011.

GORDON, C. Governmental rationality: na introduction. In: BURCHELL, G.; GORDON, C.; MILLER, P. The Foucault Effect: studies in governmentality. Chicago: The University of Chicago Press, 1991. p. 1-52.

HARCHAMBOIS, A. M.; PONTUAL, V. As ameaças do Carnaval de massa ao patrimônio de Olinda. Olinda: Centro de Estudos Avançados de Conservação Integrada, 2007.

HOBSBAWM, E. Introdução: a invenção das tradições. In: HOBSBAWM, E.; RANGER, T (orgs.). A invenção das tradições. Rio de Janeiro: Paz e Terra, 1984, p. 9-23.

HOLLANDA, B. B. B. de. País do Carnaval! País do Carnaval? (Uma apresentação alentada ao dossiê: Carnavais \& Organizações). Organizções e Sociedade, v. 20, n. 64, p. 99-109, 2013.

KNIGHTS, D. Michel Foucault. In: LINSTEAD, S. Organization theory and postmodern thought. London: Sage, 2004.

LEAL, W. B. Olinda: 100 anos de frevo. Recife: Publikimagem, 2008.

MAGALHÃES, C. A filosofia como discurso da modernidade. Ética e filosofia política, v. 2, n.1, p. 29-64, 1997.

MOTTA, F. C. P.; ALCADIPANI, R. O pensamento de Michel Foucault na teoria das organizações. Rausp, v. 39, n. 2, p. 117-128, 2004. 
NÓBREGA, T. S. Câmara Cascudo e o "Carnaval! Carnaval!": breve análise da crônica cascudiana e de perspectivas atuais do carnaval natalense. Imburana - Revista do Núcleo Câmara Cascudo de Estudos Norte-Rio-Grandenses/UFRN. n. 5, p. 115-123, 2012.

NUNES, E. D. Pequeno guia/vocabulário para a utilização da história arqueológica como instrumento de pesquisa qualitativa. Interface, v.6, n.10, p. 125-134, 2002.

OLIVEIRA, C. A vertigem da descontinuidade: sobre os usos da história na Arqueologia de Michel Foucault. História, ciências, saúde, v. 15, n. 1, p. 169-181, 2008.

ORTIZ, R. Cultura brasileira e identidade nacional. 5. ed. São Paulo: Brasiliense, 1994. QUEIROZ, M. I. P. A ordem carnavalesca. Tempo social, v. 6, n. 1-2, p. 27-45, 1994.

. Carnaval brasileiro: o vivido e o mito. São Paulo: Brasiliense, 1992.

REVEL, J. Michel Foucault: conceitos essenciais. São Carlos: Claraluz, 2005.

SOIHET, R. Reflexões sobre o carnaval na historiografia: algumas abordagens. Revista Tempo, Rio de Janeiro, n. 7, 1999.

STIVAL, M. L. Do poder ao governo e do saber a veridição. Discurso, v. 45, n. 2, p. 335344, 2016.

THIRY-CHERQUES, H. R. À moda de Foucault: um exame das estratégias arqueológica e genealógica de investigação. Lua Nova, São Paulo, n 81, 2010. p. 215-148.

TUCHERMAN, I. Michel Foucault, hoje ou ainda: do dispositivo de vigilância ao dispositivo de exposição da intimidade. In: QUEIROZ, A.; CRUZ, N. V. e. Foucault hoje? Rio de Janeiro: 7Letras, 2007.

VIDAL, F. M. C. Propostas de um Carnaval moderno em Pernambuco (1964-2004). Tempo histórico, v. 2, n. 2, p. 63-79, 2010.

VIDAL, F. M. C.; ANDRADE, E. L. Civilizar para carnavalizar: propostas de um Carnaval moderno em Pernambuco (1935-1985). In: SIMPÓSIO INTERNACIONAL PROCESSO CIVILIZADOR. CIVILIZAÇÃO E CONTEMPORANEIDADE, 12., Recife, 2009. Anais ..., Recife-PE: Fundaj, 2009.

YÚDICE, G. A conveniência da cultura: usos da cultura na era global. 2.ed. Belo Horizonte: Editora UFMG, 2013.

Data de Submissão: 18/05/2017.

Data de Aprovação: 17/05/2018. 